\title{
Effects of Rabeprazole on Plasma Gastrointestinal Peptides in Healthy Humans
}

\author{
Fumihiko Katagiri,* Yuhki Sato, Hiroki Itoh, and Masaharu Takeyama \\ Department of Clinical Pharmacy, Oita University Hospital, 1-1 Idaigaoka, Hasama-machi, Oita 879-5593, Japan
}

(Received April 1, 2005; Accepted April 18, 2005)

\begin{abstract}
Rabeprazole sodium (rabeprazole), a proton pump inhibitor (PPI), is widely used in the treatment of peptic ulcer and gastroesophageal reflux disease. Recently, some antiulcer medicines have been elucidated pharmacologically from the viewpoint of gut-regulated hormone levels. We examined the effects of rabeprazole on plasma levels of gastrointestinal peptides [gastrin, somatostatin, motilin, substance $P$, and calcitonin generelated peptide (CGRP)]. Rabeprazole at a dose of $20 \mathrm{mg}$ or placebo was orally administered to 5 healthy male volunteers aged 25-30 years. Venous blood samples were taken before and $30,60,90,120,180$, 240, and $360 \mathrm{~min}$ after administration. Plasma peptide levels were measured using a sensitive enzyme immunoassay. Compared with the response of the placebo group, rabeprazole caused significant $(p<0.05)$ increases in gastrin-, somatostatin-, and CGRP-like immunoreactive substance (IS) at 360, 180, and $240 \mathrm{~min}$, respectively. Rabeprazole significantly decreased motilin-IS levels at 180 min compared with the placebo group. However, rabeprazole had no effect on plasma substance P-IS levels. Although rabeprazole has potent antisecretry effects, the agent may have little effect on gastrointestinal peptides.
\end{abstract}

Key words — rabeprazole, proton pump inhibitor, gastrointestinal peptide, gastric emptying

\section{INTRODUCTION}

The lifetime prevalence of peptic (gastric and duodenal) ulcer disease is approximately $10 \%$, and some physicians estimate that $50 \%$ of healthy individuals experience heartburn on a daily basis. The goals of therapy for ulcers are relief from pain, pro-

\footnotetext{
*To whom correspondence should be addressed: Department of Clinical Pharmacy, Oita University Hospital, 1-1 Idaigaoka, Hasama-machi, Oita 879-5593, Japan. Tel.: +81-97-586-6113; Fax: +81-97-586-6119; E-mail: FKATA@med.oita-u.ac.jp
}

motion of healing, and prevention of recurrence. Therapeutic strategies are aimed at balancing aggressive factors (gastric acid secretion, pepsin, Helicobacter pylori infection) against defensive or cytoprotective factors (bicarbonate secretion, mucus secretion, prostaglandin production). Drugs that reduce gastric acid secretion [histamine $\mathrm{H}_{2}$-receptor antagonists and covalent inhibitors of the $\left(\mathrm{H}^{+} / \mathrm{K}^{+}\right)$ATPase proton pump of parietal cells] effectively promote healing. Cytoprotective agents and antiacids also are effective. Recurrence of ulcers is common, prompting long-term prophylactic use of $\mathrm{H}_{2}$-receptor antagonists and proton pump inhibitors (PPIs). PPIs also are effective for gastroesophageal reflux disease and are preferred for erosive esophagitis. $\mathrm{H}_{2}-$ receptor antagonists are used extensively for maintenance therapy for reflux.

The ultimate mediator of acid secretion is the proton pump of the apical membrane of parietal cells. Since this pump is unique to parietal cells, a number of specific inhibitors of it have been developed. The agents offer a means to inhibit acid secretion to any desired level. They are especially useful in patients with hypergastrinemia and may be valuable in those whose peptic ulcer disease is not well controlled by $\mathrm{H}_{2}$-receptor antagonists. Rabeprazole sodium (rabeprazole) was introduced in 1986 as the third PPI, which potently inhibits gastric acid secretion. Today, rabeprazole is widely used in treatment of peptic ulcer and gastroesophageal reflux disease. ${ }^{1)}$

One of the gastrointestinal motility regulatory factors responsible for the empirical effects of PPIs has been assumed to be the induction of changes in the levels of peptides (gastrin, somatotatin and motilin) in plasma. In gastroprotective function as a neural emergency system, sensory afferent neurons in the gastrointestinal mucosa regulate neuropeptide [calcitonin gene-related peptide (CGRP), and tachykinins (substance $\mathrm{P}$ etc.)] levels and play various physiological roles. ${ }^{2)}$

In recent years, some antiulcer medicines have 
been elucidated pharmacologically from the viewpoint of gut-regulated hormone levels. Among the agents, $\mathrm{H}_{2}$-receptor antagonists change gut-regulated hormones levels in healthy human plasma. ${ }^{3,4)}$ Furthermore, we revealed that single administration of the PPIs omeprazole and lansoprazole alter gastrointestinal peptides. ${ }^{5,6)}$ These results indicate new pharmacological effects of the medicines.

The purpose of this study was to determine the effects of rabeprazole on plasma levels of gut-regulatory peptides [gastrin-, somatostatin-, and motilinimmunoreactive substance (IS)] and gastrointestinal mucosa-regulatory neuropeptides (substance P- and CGRP-IS) in healthy humans and to determine other pharmacologic effects in addition to the antisecretory effects.

\section{MATERIALS AND METHODS}

Materials — Rabeprazole (Prariet tablets; Eisai Co., Ltd., Tokyo, Japan) were used. Lactose (Merck Hoei Co., Ltd., Osaka, Japan) was used as a placebo. Synthetic human gastrin I, somatostatin, motilin, CGRP, and its fragment (8-37), and substance $P$ were purchased from the Peptide Institute (Osaka, Japan). Fragment gastrin I (2-17) was purchased from Sigma Chemical (St. Louis, MO, U.S.A.) Antiserum to gastrin (A600/R1B) was purchased from Biogenesis (Poole, U.K.), CGRP (CA1132) was purchased from Affiniti Research Products Ltd. (Nottingham, U.K.), somatostatin (RA-08-108) and substance P (RA-08-095) from Cambridge Research Biochemicals (Cambridge, U.K.) and motilin (Y121) from Yanaihara Institute (Shizuoka, Japan). All other reagents were of analytical reagent grade from commercial sources.

Volunteers - Five healthy male volunteers, aged 25-30 years (mean 27 years) and weighing 55-68 kg (mean $63 \mathrm{~kg}$ ), participated in the study. Each volunteer received information on the scientific purpose of the study and gave written, informed consent. The study protocol was approved by the Ethical Committee of Oita Medical University. The volunteers did not receive any medication 1 week before the study, and fasted for $3 \mathrm{hr}$ before the study commenced and during the experiments.

Study Schedule — Rabeprazole $(20 \mathrm{mg}$ ) or placebo was administered orally with $100 \mathrm{ml}$ of water. Each volunteer recieved these agents at 4-week intervals. The dose of rabeprazole in this study was the maximum daily dose in clinical therapy. Venous blood samples $(10 \mathrm{ml})$ were taken from a forearm vein before and at 30,60,90,120,180, 240, and $360 \mathrm{~min}$ after administration. The study was carried out from 11:30 to 17:30.

Determination of Rabeprazole Concentrations in Plasma — The plasma concentration of rabeprazole was determined using the modified method of Nakai et al. ${ }^{7)}$ Standard rabeprazole was supplied by Eisai Co., Ltd. A 1-ml plasma sample was placed in glass tube containing $100 \mu \mathrm{l}$ of a $1 \%$ aqueous solution of diethylamine. To this solution, a $100-\mu$ l aliquot of $0.1 \%$ diethylamine in methanol, $1.0 \mathrm{ml}$ of Britton-Robinson buffer ( $\mathrm{pH} 10.38$ ), and $4.0 \mathrm{ml}$ of ethyl acetate were added. The mixture was shaken for $10 \mathrm{~min}$ and centrifuged for $5 \mathrm{~min}$ at $1500 \mathrm{~g}$. The organic layer was evaporated to dryness at $40^{\circ} \mathrm{C}$ under nitrogen. The residue was dissolved in $700 \mu \mathrm{l}$ of $0.1 \%$ diethylamine in methanol and mixed for $1 \mathrm{~min}$. A 200- $\mu$ l aliquot was injected onto the column. HPLC was carried out using a C18 column (Cosmosil 5C18-AR; Nacalai Tesque, Kyoto, Japan) with UV detection at $288 \mathrm{~nm}$, and acetonitrile-phosphate buffer $0.1 \mathrm{M}(\mathrm{pH} 7.0)$ $(280: 720)$ was used as the mobile phase at a flow rate of $1.4 \mathrm{ml} / \mathrm{min}$.

Enzyme Immunoassay of Gastrin, Somatostatin, Motilin, CGRP, and Substance $\mathbf{P}$ - The blood samples were placed in chilled tubes containing 500 kallikrein inhibitor units $/ \mathrm{ml}$ of aprotinin and $1.2 \mathrm{mg} / \mathrm{ml}$ of EDTA. After centrifugation, plasma samples were diluted five-fold with $4 \%$ acetic acid (pH 4.0) and loaded onto a C18 reversedphase cartridge (Sep-Pak C18; Millipore Corp., Milford, MA, U.S.A.). After washing with $4 \%$ acetic acid, plasma peptides were eluted with $70 \%$ acetonitrile in $0.5 \%$ acetic acid ( $\mathrm{pH} 4.0)$. Eluates were concentrated by spin-vacuum evaporation, lyophilized, and stored at $-40^{\circ} \mathrm{C}$ until assayed. The recovery of plasma gastrin-, somatostatin-, motilin-, VIP-, CGRP-, and substance P-IS was $>90 \%$ with this extracton procedure (data not shown).

The enzyme immunoassay for gastrin, ${ }^{8)}$ somatostatin, ${ }^{9)}$ motilin, ${ }^{10)}$ CGRP ${ }^{11)}$ and substance $\mathrm{P}^{12)}$ were performed as previously described. The assay was performed using a delayed addition method. Separation of bound and free antigen was performed on an anti-rabbit IgG (55641, ICN Pharmaceuticals, Inc., Ohio, U.S.A.)-coated immunoplate (NuncImmuno Module Maxisorp F8, InterMed, Denmark). The fluorescent product 4-methylumbelliferon was measured with an MTP-100F microplate reader (Corona Electric, Ibaraki, Japan). Gastrin I (2-17), hu- 
man somatostatin, motilin, CGRP (8-37), and substance $\mathrm{P}$ were conjugated with $\beta$-D-galactosidase (Boehringer Mannheim, Germany) with $N-(\varepsilon-$ maleimidocaproyloxy)-succimide according to the method of Kitagawa et al. ${ }^{13)}$ The EIA for gastrin, somatostatin, motilin, CGRP, and substance $P$ was specific and highly sensitive to detection limits of $0.04,0.10,0.80,0.08$, and $0.40 \mathrm{fmol} / \mathrm{well}$, respectively

Statistical Analysis — Results are expressed as mean \pm S.D. Comparison of the mean values was performed using a repeated measures paired $t$-test. A $p$-value of less than 0.05 indicated a statistically significant difference.

\section{RESULTS AND DISCUSSION}

The profiles of mean plasma rabeprazole concentrations against time after oral administration of $20 \mathrm{mg}$ of the drug are shown in Fig. 1. The plasma levels were the highest at $180 \mathrm{~min}(307.6 \pm 40.1 \mathrm{ng} /$ $\mathrm{ml})$.

Rabeprazole caused a significant increase in gastrin-IS at $360 \mathrm{~min}(39.8 \pm 3.2 \mathrm{pg} / \mathrm{ml})$, compared with the response in the placebo group $(29.7 \pm 6.0 \mathrm{pg} /$ ml) (Fig. 2a). Figure 2b shows plasma motilinIS levels after administration of rabeprazole. Rabeprazole significantly decreased motilin-IS levels at $180 \mathrm{~min}(12.7 \pm 1.7 \mathrm{pg} / \mathrm{ml})$, compared with the response in the placebo group $(17.2 \pm 2.6 \mathrm{pg} /$ $\mathrm{ml})$. Single administration of rabeprazole caused an increase in plasma somatostatin-IS levels at $180 \mathrm{~min}$ $(11.9 \pm 2.8 \mathrm{pg} / \mathrm{ml})$ compared with the placebo group $(9.1 \pm 1.9 \mathrm{pg} / \mathrm{ml})$ (Fig. 1c). Rabeprazole caused a significant increase in plasma CGRP-IS levels at $240 \mathrm{~min}(36.3 \pm 1.4 \mathrm{pg} / \mathrm{ml})$, compared with the placebo group $(27.1 \pm 10.5 \mathrm{pg} / \mathrm{ml})$ (Fig. $2 \mathrm{~d})$. The levels of plasma substance P-IS did not change (Fig. 2e).

Gastrin, a 17-amino acid residue polypeptide, stimulates gastric acid secretion. This peptide is associated with a mechanism of gastrointestinal motility involving the cholonergic nervous system. ${ }^{14)}$ In Fig. 2a, the temporary elevation of gastrin-IS levels of placebo might have been caused by direct stimulation of gastric mucosal $\mathrm{G}$ cells. It has been reported that not only long-term administration ${ }^{15)}$ but also single administration ${ }^{16)}$ of rabeprazole causes increases in plasma gastrin, resulting in hypergastrinemia. Rabeprazole produces a rapid, potent, and long-acting inhibition of gastric acid secretion ${ }^{17)}$ in association with a significant increase in plasma

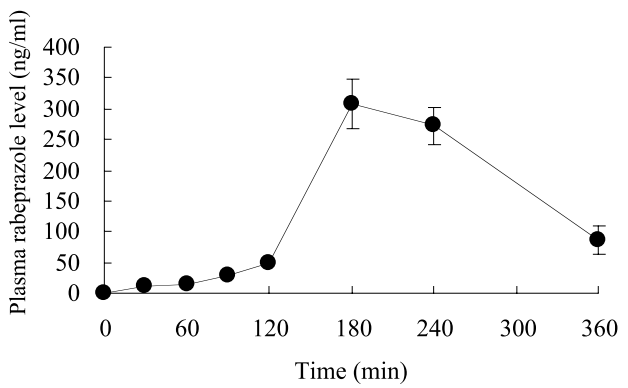

Fig. 1. Plasma Rabeprazole Levels after Oral Administration of $20 \mathrm{mg}$

Each value represents the mean \pm S.D., $n=5$.

gastrin levels. In this study, plasma gastrin-IS levels were significantly increased at $360 \mathrm{~min}$. A previous report also showed that administration of rabeprazole caused a significant increase at $5 \mathrm{hr} .{ }^{16)}$ Our results might indicate hypergastrinemia due to rabeprazole administration.

Motilin, a 22-amino acid residue polypeptide, has powerful fundic pouch motor-stimulating activity. ${ }^{18)}$ It plays an important physiologic role in intestinal contractility and is one of the most important factors controlling the regular occurrence of phase3 contractions of the migrating motor complex. ${ }^{19)}$ In this study, motilin-IS levels were decreased at $180 \mathrm{~min}$. We hypothesized that rabeprazole slows gastric emptying. Generally, PPIs are assumed to delay gastric emptying, ${ }^{20,21)}$ but there is a report that rabeprazole does not affect gastric emptying. ${ }^{22)}$ Our result differed from those of the previous report, but because in our study motilin-IS levels decreased at only one point $(180 \mathrm{~min}$ ), and at $240 \mathrm{~min}$ the decrease recovered to the baseline level, rabeprazole may have little effect on gastric emptying.

Somatostatin, a 14-amino acid residue polypeptide, inhibits the secretion of other hormones, including gastrin, insulin, and motilin. ${ }^{23)}$ In the gastrointestinal tract, gastric acid and pepsin secretion and gastric emptying are inhibited by somatostatin. Somatostatin, which is distributed widely in the gastrointestinal tract, participates in the control of gut motility by exerting both inhibitory and stimulatory effects. In other words, in the interdigestive state somatostatin induces phase- 3 activities, and in the digestive state it inhibits gastric emptying and slows gastrointestinal transit. In this study, plasma somatostatin-IS levels were significantly increased at $180 \mathrm{~min}$. Although gastrin-IS levels were not decreased, motilin-IS levels were. The somatostatin levels increased corresponding to the plasma 
(a)

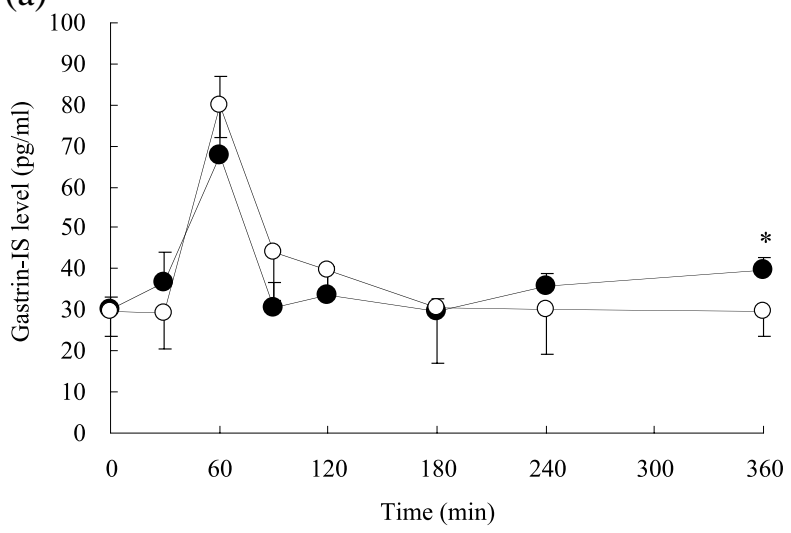

(b)

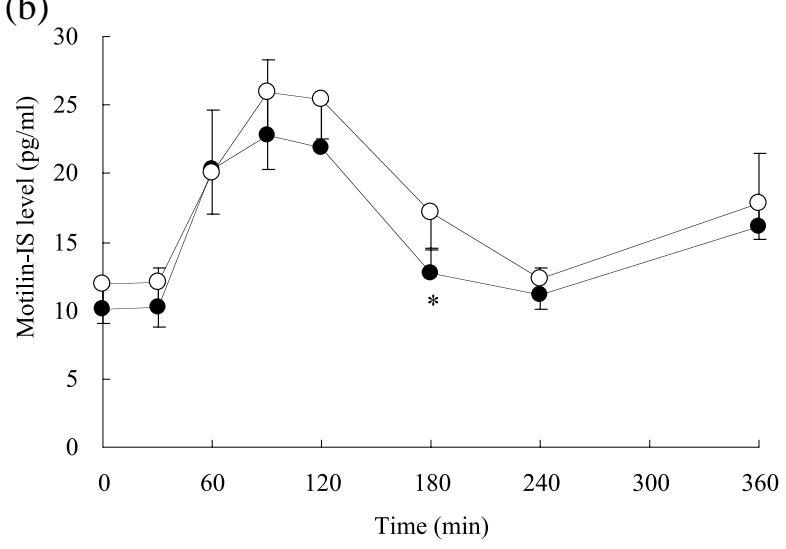

(c)

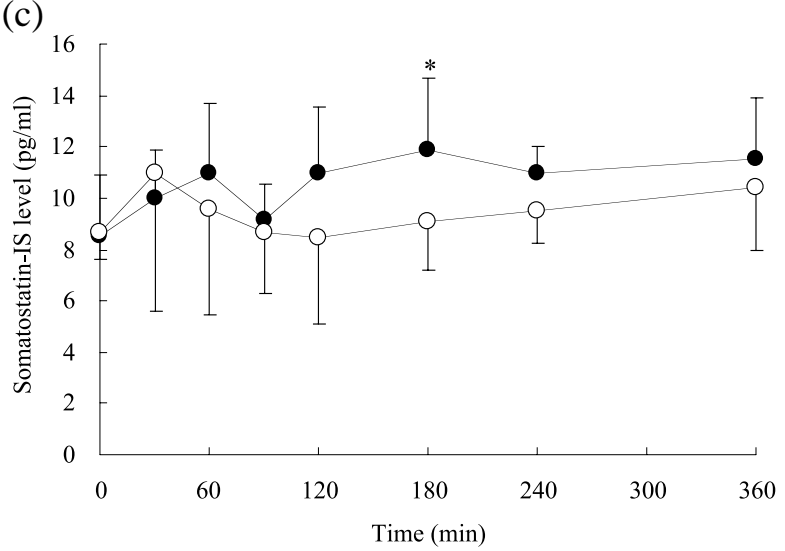

(d)

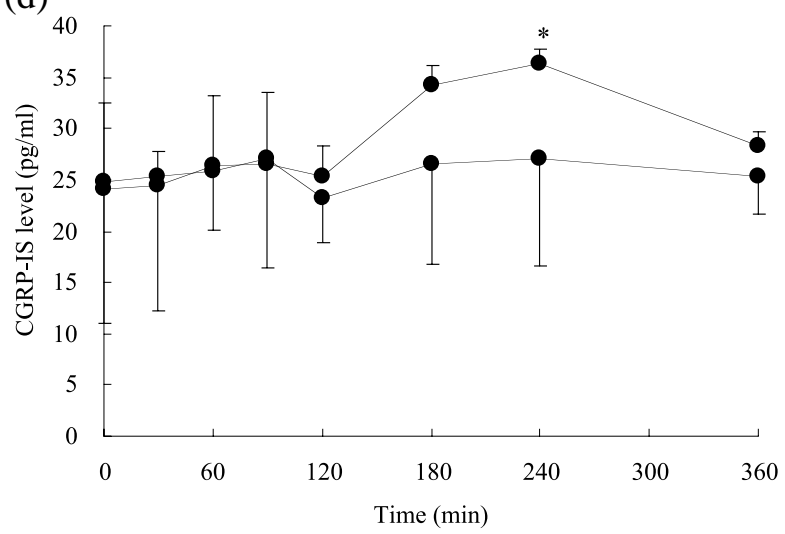

(e)

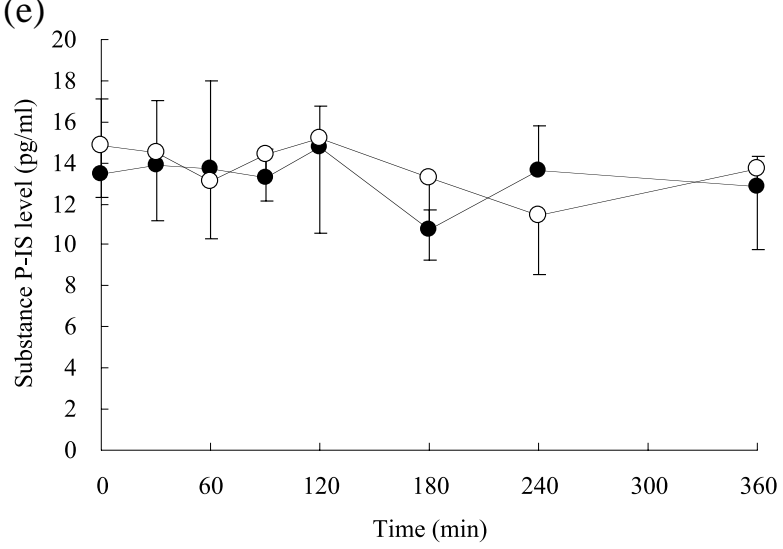

Fig. 2. Effects of Rabeprazole ( ) or Placebo $(\bigcirc)$ on Plasma Gastrin- (a), Motilin- (b), Somatostatin- (c), CGRP- (d), and Substance PIS (e) Levels

Each value represents the mean \pm S.D., $n=5 .{ }^{*} p<0.05$ and $* * p<0.01$, significantly different compared with placebo group.

rabeprazole level. We hypothesized that rabeprazole might directly stimulate D cells, which secrete somatostatin.

CGRP is a powerful vasoactive substance that is released from the sensory afferent nerve endings against gastric mucosal injury in the stomach. CGRP increases gastric mucosal flow as a gastroprotective factor. ${ }^{2)}$ Substance P and tachykinins coexist with CGRP in the sensory afferent neurons of the gastrointestinal mucosa and are released with acetylcholine in response to depolarizing stimuli in the enteric nervous system. ${ }^{24)}$ In this study, rabeprazole caused a significant increase in CGRP-IS but did not alter substance P-IS levels. Tahashi et al. ${ }^{25)} \mathrm{re}-$ 
ported the drug has protective effects on the gastric mucosa, which are assumed to be due to nitric oxide (NO) ${ }^{26)}$ It is known that CGRP acts at the CGRP-1 receptor, located on blood vessel endothelium, and promotes NO synthesis. ${ }^{27)}$ We believe that the cytoprotective effects of rabeprazele might be not via CGRP-tachykinin sensory afferent nerves but via the CGRP-NO system.

In conclusion, rabeprazole exhibits potent inhibition of gastric acid secretion due to inhibition of $\left(\mathrm{H}^{+} / \mathrm{K}^{+}\right)$-ATPase, but has little effect on gut-regulatory hormones involved in gastric acid secretion. Although no significant difference was not observed in the gastroprotective function in the rabeprazole group, our results might support the former report that rabeprazole has cytoprotectives effects associated with the CGRP-NO system. Although we did not find novel effects of rabeprazole, the agent might be clinically useful without side effects related to gastrointestinal hormones.

\section{REFERENCES}

1) Morii, M., Takata, H., Fujisaki, H. and Takeguchi, N. (1990) The potency of substituted benzimidazoles such as E3810, omeprazole, Ro 18-5364 to inhibit gastric $\mathrm{H}^{+}, \mathrm{K}^{+}$-ATPase is correlated with the rate of acid-activation of the inhibitor. Biochem. Pharmacol., 39, 661-667.

2) Holzer, P. (1998) Neural emergency system in the stomach. Gastroenterology, 114, 823-839.

3) Takeyama, M., Itoh, H., Hayashi, T. and Nagano, T. (1998) Effects of histamine $\mathrm{H}_{2}$-receptor antagonists on human plasma levels of motilin, gastrin, secretin and somatostatin. Pharm. Pharmacol. Commun., 4, 591-594.

4) Itoh, H., Naito, T. and Takeyama, M. (2002) Effects of histamine $\mathrm{H}_{2}$-receptor antagonists on human plasma levels of calcitonin gene-related peptide, substance $\mathrm{P}$ and vasoactive intestinal peptide. $J$. Pharm. Pharmacol., 54, 1559-1563.

5) Katagiri, F., Inoue, S., Itoh, H. and Takeyama, M. (2005) Omeprazole raises somatostatin and motilin in human plasma. Biol. Pharm. Bull., 28, 370-373.

6) Katagiri, F., Inoue, S., Sato, Y., Itoh, H. and Takeyama, M. (2005) Lansoprazole raises somatostatin, calcitonin gene-related peptide and substance P levels in healthy human plasma. J. Health. Sci., 51, 294-299.

7) Nakai, H., Shimamura, Y., Kanazawa, T., Yasuda, S. and Kayano, M. (1994) Determination of new $\mathrm{H}^{+}-$ $\mathrm{K}^{+}$ATPase inhibitor (E3810) and its four metabo- lites in human plasma by hight-performance liquid chromatography. J. Chromatogr., 660, 211-220.

8) Takeyama, M., Matsuo, H. and Mori, K. (1993) Enzyme immunoassay of gastrin in human plasma. Chem. Pharm. Bull., 41, 2197-2199.

9) Katagiri, F., Inoue, S., Sato, Y., Itoh, H. and Takeyama, M. (2005) Ecabet sodium raises plasma calcitonin gene-related peptide and substance $\mathrm{P}$ in healthy human subjects. J. Pharm. Pharmacol., in press.

10) Naito, T., Itoh, H. and Takeyama, M. (2002) Hangeshashin-to raises levels of somatostatin, motilin and gastrin in the plasma of healthy subjects. Biol. Pharm. Bull., 25, 327-331.

11) Nagano, T., Ikawa, K. and Takeyama, M. (1998) Enzyme immunoassay of calcitonin gene-related peptide-like immunoreactive substance in human plasma and saliva. Jpn. J. Hosp. Pharm., 24, 363369.

12) Takeyama, M., Mori, K., Takayama, F., Kondo, K., Kitagawa, K. and Fujii, N. (1990) Enzyme immunoassay of a substance P-like immunoreactive substance in human plasma and saliva. Chem. Pharm. Bull., 38, 3494-3496.

13) Kitagawa, T., Shimozono, T., Aikawa, T., Yoshida, T. and Nishimura, H. (1981) Preparation and characterization of hetero-bifunctional cress-linking reagents for protein modifications. Chem. Pharm. Bull., 29, 1130-1135.

14) Szelenyi, I. (1980) Cholinergic components in the gastrin pathway of gastric acid stimulation. Experientia, 36, 973-974.

15) Williams, M. P., Blanshard, C., Millson, C., Sercombe, J. and Pounder, R. E. (2000) A placebocontrolled study to access the effects of 7-day dosing with 10, 20 and $40 \mathrm{mg}$ rabeprazole on 24-h intragastric acidity and plasma gastrin in healthy male subjects. Aliment. Pharmacol. Ther., 14, 691699.

16) Lew, E. A., Barbuti, R. C., Kovacs, T. O. G., Sytnic, B., Humphries, T. J. and Walsh, J. H. (1998) An ascending single-dose safety and tolerance study of an oral formulation of rabeprazole (E3810). Aliment. Pharmacol. Ther., 12, 667-672.

17) Ohning, G. V., Barbuti, R. C., Kovacs, T. O. G., Sytnik, B., Humphries, T. J. and Walsh, J. H. (2000) Rabeprazole produces rapid, potent, and long-acting inhibition of gastric acid secretion in subjects with Helicobacter pylori infection. Aliment. Pharmacol. Ther., 14, 701-708.

18) Brown, J. C. and Parkes, C. O. (1967) Effect on fundic pouch motor activity of stimulatory and inhibitory fractions separated from pancreozymin. Gastroenterology, 53, 731-736. 
19) Itoh, Z., Honda, R., Hiwatashi, K., Takeuchi, S., Aizawa, I., Takayanagi, R. and Couch, E. F. (1976) Motilin-induced mechanical activity in the canine alimentary tract. Scand. J. Gastroenterol. Suppl., 39, 93-110.

20) Rasmussen, L., Oster-Jorgensen, E., Qvist, N. and Pedersen, S. A. (1999) The effects of omeprazole on intragastric $\mathrm{pH}$, intestinal motility, and gastric emptying rate. Scand. J. Gastroenterol., 34, 671675.

21) Vidon, N., Dutreuil, C., Scoule, J. C. and Delchier, J. C. (1993) Does lansoprazole influence postprandial digestive function? Aliment. Pharmacol. Ther., 7, 629-634.

22) Michael, P. J., Dhiren, S. and Christine, C. E. (2003) Effects of rabeprazole sodium on gastric emptying, electrogastrography, and fullness. Dig. Dis. Sci., 48, 69-73.

23) Ling, N., Burgus, R., Rivier, J., Vale, W. and Brazeau, P. (1973) The use of mass spectrometry in deducing the sequence of somatostatin-a hypothalamic polypeptide that inhibits the secretion of grouwth hormone. Biochem. Biophys. Res. Commun., 50, 127-133.

24) Hellström, P. M., Söder, O. and Theodorsson, E. (1991) Occurrence, release, and effects of multiple tachykinins in cat colonic tissues and nerves. Gastroenterology, 100, 431-440.

25) Tahashi, Y., Asada, S., Umegaki, E., Takeuchi, H., Matsumoto, A., Hirata, I. and Ohshiba, S. (1993) Effect of long-term administration of omeprazole (OMP), lansoprazole (LPZ) and E-3810 on gastric mucin. Ulcer Res., 21, 46-49.

26) Watanabe, T., Higuchi, K., Tominaga, K., Fujiwara, Y. and Arakawa, T. (2000) Cytoprotective effect of rabeprazole against ethanol-induced gastric mucosal damage: possible involvement of nitric oxide. Drugs Exp. Clin. Res., 26, 41-45.

27) Strecker, T., Dux, M. and Messlinger, K. (2002) Nitric oxide releases calcitonin-gene-related peptide from rat dura mater encephali promoting increases in meningeal blood flow. J. Vasc. Res., 39, 489-496. 